Віктор Коцур

Академік НАПН (дійсний член) доктор історичних наук, професор Університету Григорія Сковороди в Переяславі (Переяслав, Україна)

\section{Victor Kotsur}

Academician (the real member) of the Academy of the Educational Sciences, Doctor of History (Dr. habil.), Professor of the Gregory Skovoroda University in Pereyaslav (Pereyaslav, Ukraine)

ORCID: 0000-0003-4968-4813

ResearcherID: 1760067/victor-kotsur/ phdpu.edu@gmail.com

Андрій Бойко-Гагарін

доктор історичних наук, старший зберігач фондів відділу

«Музей грошей»,

Управління зв'язків 3

громадськістю та фінансової обізнаності,

Департамент комунікацій, Національний банк України, доцент кафедри мистецтвознавчої експертизи ім. Казимира Малевича,

Національної академії керівних кадрів культури і мистецтв (Київ, Україна)

\author{
Andrii Boiko-Haharin \\ Doctor of history (dr. habil), \\ the senior treasurer «Museum of \\ money», \\ National bank of Ukraine \\ associate professor of art expertise \\ university departament, \\ National academy of managing staff \\ of culture and arts \\ (Kyiv, Ukraine)
}

ORCID: 0000-0003-4610-3665

ResearcherID: $\mathrm{n}-6985-2017$

boiko.gagarin@ukr.net

\section{Володимир Кашперський} кандидат історичних наук начальник головного управління вищої освіти і освіти дорослих Міністерство освіти і науки України (Київ, Україна)
Volodymyr Kashperskyi $\mathrm{PhD}$, head of the main department of higher education and adult education Ministry of education and science of Ukraine (Kyiv, Ukraine)

ORCID: 0000-0003-0633-8347

v_kashperskyy@mon.gov.ua 


\section{ЗНАХІДКИ ПІЗНЬОРИМСЬКИХ МОНЕТ В УКРАЇНІ: ІСТОРІЯ ДОСЛІДЖЕНЬ}

\section{LATE ROMAN COIN FINDS IN UKRAINE: HISTORY OF RESEARCH}

\section{Анотація.}

Мета статmi. Головною метою статті є висвітлення історіографії вивчення нумізматами в Україні знахідок монет Західної Римської імперіі nеріоду IV - поч. V cm. в історіографії. Методологія дослідження. У прочесі наукового опрацювання теми було використано загальнонаукові методи: аналітичний, хронологічний, та топографічний, а також джерелознавчі методи: критичний, метрологічний та іконографічний. Наукова новизна полягає у тому, щзо вперше в науковий обіг уведені висновки щуодо стану наукової розробки топографії знахідок пізньоримських монет на території України, наведені деякі спостереження щзодо введення до наукового обігу изих знахідок.

Висновки дослідження. Більша частина знахідок, щуо введені нумізматами в науковий обіг, відноситься до знайдених у ХІХ столітті, лише стосовно частини з них збережено відомості про передавання їх до фондів музеїв. В подальшому, практично, одні і ті самі опубліковані знахідки повторно вводились у науковий обіг, переопубліковуючись у різних топографіях знахідок, дещуо доповнюючись новими, виявленими знахідками монет Західної Римської імперії IV - поч. V cm. Слід відмітити також той факт, щуо здебільшого в описах знахідок наявна достатьно скорочена та кротка інформація, відсутні описи монет, вказівка на їх різновиди, найчастіше вказується емітент, номінал, рідше передається легенда. Прикрим фактом стало потрапляння сильно пошкоджених монет, ідентифікачія яких мжлива лише приблизна, а в опрацьованих авторами топографіях таких повідомлень виявилась досить суттєва кількість.

Найбільш відомими скарбами та знахідками монет, які було опубліковано низкою авторів та згадано в численних публікачях науково-популярного характеру, стали: скарб із с. Ласків Володимир-Волинського району, сумнівний скарб римських монет з історичної Оболоні, знахідка в Успенському соборі, інформація про які потрапила, практично, до кожного топографічного зведення та до всіх складених протягом ХХ сm. археологічних карт нумізматів, внаслідок чого вони стали класичними скарбами.

У сучасній украӥнській нумізматищі науковцями публікуються знахідки, виявлені як під час офіиійних археологічних професійних пошуків, так $i$ несанкціонованих аматорських та випадкових знахідок. На нинішньому етапі вивчення цьвого питання актуальною постає необхідність складання повної топографічної карти знахідок римських монет IV - поч. V cm. зі здійсненням їх 
аналізу для отримання висновків щуодо поширення та побутування цих монет на території України. Перспективою подальших досліджень ми бачимо введення y науковий обіг та опраџювання нових знахідок римських монет вказаного періоду на території Украӥни для створення найбільш якісної та наповненої топографічної карти.

Ключові слова: Римська імперія, топографія знахідок, торгові зв'язки, монети імпепратора Костянтина, монети імпепратора Констанція, історіографія, нумізматичні дослідження в Україні.

\section{Summary.}

Analyzing the published researches by previous researchers of new finds of coins of the different periods we were determining as one of the actual directions of research in the medieval numismatics in Ukraine. Examining the scientific achievements of the Ukrainian numismatists, we have determined a significant gap in the focus of research on the findings of coins of the Western Roman Empire and the territory of Ukraine, in particular, the sporadic conclusions are also published by researchers analyzing the existence of Roman coins in this period. The aim of the study. The main purpose of the article is to discover the historiography of the study of the findings of coins of the Western Roman Empire in the period of the IV - the beginning of the $V$ cent. in Ukrainian historiography. Research methodology. In the process of scientific research of the topic the general scientific methods were used: analytical, chronological, and topographic, as well as special methods: critical, metrological and iconographic. The scientific novelty is that for the first time conclusions of scientific current development of the topography of finds of late Roman coins on the territory of Ukraine were introduced into scientific circulation, some observations on the introduction of these finds into scientific circulation were given.

The Conclusions. Most of the finds introduced by numismatists into scientific circulation belong to those found in the nineteenth century, about only part of which are preserved information about their transfer to museum collections. Subsequently, almost the same published finds were re-introduced into scientific circulation, republished in various topographies of finds, somewhat supplemented by new discoveries of coins of the Western Roman Empire. It should also be noted that in most cases the descriptions of the finds contain sufficiently abbreviated and concise information, there are no descriptions of coins, an indication of their varieties, mostly the issuer is indicated, the denomination, less often - the legend is transmitted. It is an unfortunate fact that severely damaged coins are found, the identification of which becomes possible only approximately, and in the topographies of such messages processed by the authors a rather significant number.

The most famous treasures and finds of coins, which have been published by a number of authors and mentioned in numerous popular science publications, are the 
treasure from the village of Laski, the dubious treasure of Roman coins from historical Obolon, the find in the Uspensky and Vydubichi Cathedrals - information about which compilations and all compiled archaeological maps of numismatists during the twentieth century - thus becoming a classic treasures.

In modern Ukrainian the numismatics and scientists publishing the findings discovered during the official archaeological professional searches, as well as unauthorized amateur and accidental finds. At the present stage of studying this issue, it is necessary to compile a complete topographic map of the findings of Roman coins of IV-V centuries with their analysis to obtain conclusions on the distribution and existence of these coins in Ukraine.

Finds of the Roman gold coins always attract a special and more attention, so there are several separate examples of similar finds in Ukraine, published by scientists. The finds of Roman gold medallions deserve special attention, because each of them is extremely rare. Information on individual numismatic finds in the process of official archaeological exploration with available coins of the Western Roman Empire was published by archaeologists. In ancient times, it was common to use coins as jewelry - giving them a «second life». In the outlined chronological period, the coin finds also differed in a significant number of silver and gold coins with available soldered ears - turned into pendants, neck ornaments.

As the prospects of further research we see we see the introduction into scientific circulation and processing of new finds of Roman coins of this period in Ukraine to display the highest quality and complete topographic map.

Keywords: Roman Empire, topography of finds, trade relations, coins of Emperor Constantine, coins of Emperor Constantius, historiography, numismatic research in Ukraine.

Постановка проблеми. Аналізові накопичених знань попереднім дослідниками, їх публікацію та введення у наковий обіг нових знахідок монет різних періодів ми визначали як один із актуальних напрямків досліджень в галузі середньовічної нумізматики в Україні ${ }^{1}$. Безумовно, ця теза також стосується й античної нумізматики так само, як і питання історії грошового обігу в цілому будь-якого періоду. Дослідивши науковий доробок вітчизняних нумізматів, нами виявлено значну прогалину у фокусі дослідження знахідок монет Західної Римської імперії на території України, зокрема виглядають спорадичними опубліковані дослідниками висновки 3 аналізом побутування римських монет в цей період.

Аналіз останніх досліджень і публікацій. Попри численні публікації, сфокусовані на дослідженні монет та грошового обігу Античного періоду, суто історіографічних праць серед них, які б висвітлювали процес вивчення знахідок

\footnotetext{
${ }^{1}$ Коцур 2013.
} 
монет Західної Римської імперії у період з початку IV й до початку V століть, ми не знаходимо. Сдиною, пов'язаною $з$ указаною тематикою та грунтовною публікацією, виявилася історіографічна праця В. Коцура, присвячена досліженню у вітчизняній історичній науці феномену скарбознавства, який висвітлюєтьс на грунті публікацій про знахідки та аналіз виявлених скарбів 3 монетами різних історичних періодів ${ }^{1}$. Власне історіографічних праць, присвячених знахідкам монет пізньої Римської імперії вказаного періоду, не виявлено.

Теоретико-методологічні основи дослідження. У процесі наукового вивчення теми були використані такі загальнонаукові методи: ілюстративний, аналітичний та хронологічний, особливу увагу приділено топографічному методу, дослідження доповнювалося джерелознавчими методами: критичним та метрологічним ${ }^{2}$. Важливі дані щодо знахідок монет у вказаному хронологічному періоді виявлено на різноманітних WEB-pecypcax та в межах інформації, розміщеної на сайтах музеїв, науковий потенціал та цінність яких у процесі наукового дослідження не викликала сумнівів ${ }^{3}$.

Формулювання цілей статті. Головна мета статті - введення у науковий обіг результатів історіографічного дослідження процесу вивчення побутування монет пізньої Римської імперії на території України, визначення стану вивчення цієї тематики у вітчизняній нумізматиці.

\section{Виклад основного матеріалу дослідження.}

Дослідження античної нумізматики стрімко набирає обертів у сучасній Україні. Зокрема В.Коцуром уведено до наукового обігу деякі знахідки античних монет на Переяславщині, що здійснено у фокусі вивчення нумізматичної колекції Національного історико-етнографічного заповідника «Переяслав» ${ }^{4}$. Новітні дослідження у фіксації та введенні в науковий обіг знахідок античних монет здійснені В. Орликом, В. Коцуром та Л. Циганенко M. Мельчареком та В. Орликом досліджено скарб ольвійських монет 6 . В. Орликом також приділено увагу іншим важливим аспектам у вивченні проблемних питань античної нумізматики в Україні, зокрема: новим знахідкам кізікінів, монет Мітрідата Євпатора та уточнення до питання існування грошового обігу на території Дніпровського правобережного лісостепу (V - I ст. до н. е. $)^{7}$. Публікації даних про нові надходження античних монет до колекцій музеїв опубліковано А. Бойком-Гагаріним спільно із О. Дацюк ${ }^{8}$ рідкісну

\footnotetext{
${ }^{1}$ Коцур 2017: 15-32.

${ }^{2}$ Калакура, Войцехівська 2002: 120.

${ }^{3}$ Орлик 2013: 129-133; Орлик В., Орлик С., Лузанова Г. 2020: 392-422.

${ }^{4}$ Коцур 2020: 144-164.

${ }^{5}$ Орлик, Коцур, Цыганенко 2019: 37-48; Орлик 2018: 13-14.

${ }^{6}$ Mielczarek, Orlyk 2019: 33-39.

${ }^{7}$ Орлик 2020-a: 5-15; Орлик 2020-b: 9-13; Орлик 2020-c: 5-42. Орлик 2020.

8 Дацюк, Бойко-Гагарін 2020: 20-22.
} 
знахідку монет Речі Посполитої із римським денарієм - спільно з К. Мизгіним ${ }^{1}$. Про знахідку та передачу до лабораторії археологічних досліджень при кафедрі iсторії та культури України ДВНЗ «Переяслав-Хмельницький державний педагогічний університет імені Григорія Сковороди» монет Ольвії повідомив О. Колибенко ${ }^{2}$. Монету Римської імперії було також виявлено на території скансену «Музею народної архітектури та побуту Середньої Наддніпрянщини»³.

Проаналізувавши науковий доробок вітчизняних учених в аспекті вивчення знахідок античних монет на території України, нами було виявлено прогалину та факт спорадичності досліджень та аналізу знахідок монет Західної Римської імперії у період 3 початку IV й до середини VIII століть. Аналіз найбільш суттєвих публікацій з обраної теми наведемо нижче.

Однією 3 перших наукових публікацій зі згадками про знахідки пізньоримських монет стала згадка про знахідку золотої монети Євдокії, дружини Феодосія II (408 - 450 рр.), виявлену археологами 1823 р. у Введенській церкві на перетині вулиць Ярославської та Почайнинської у м. Києві. Ця знахідку зафіксовано у зведеній археологічній карті Київщини, що була складена вченим Антоновичем ${ }^{4}$. Досліджуючи археологічні знахідки на Київщині, цю ж монету згодом згадує в своїй роботі М. Біляшівський 5 . Цього ж року було опубліковано повідомлення М. Петрова про сенсаційну знахідку величезного скарбу в Успенському соборі на терирторії Києво-Печерської Лаври та золотий медальйон імператора Констанція в його складі6.

Однією із найдавніших зафіксованих знахідок $є$ широко відомий скарб золотих та срібних монет, виявлений 1610 р. селянином Кирилом Божком у с. Ласків Володимир-Волинського району Волинської області. У складі депозиту були римські медальйони номіналом 6 та 9 солідів IV ст. ${ }^{7}$

На межу XIX та XX століть припадає найбільша наукова активність відомого українського нумізмата В. Ляскоронського. У 1901 p. було опубліковано розвідку вченого про знахідки римських монет на території середнього Подніпров'я ${ }^{8}$, у 1927 р. опубліковано знахідки на Київщині ${ }^{9}$. Невиданою залишилася праця вченого, підготовлена того ж року і присвячена обігові римських монет у Південній Русі, що збережена в Бібліотеці ім. М. Максимовича та може бути видана читачам у вигляді рукопису автора 3 авторськими помітками ${ }^{10}$.

\footnotetext{
${ }^{1}$ Бойко-Гагарин, Мызгин: 240-247.

${ }^{2}$ Колибенко, Колибенко: 18-21.

${ }^{3}$ Прядко, Юрченко 2017: 84-91.

${ }^{4}$ Антонович 1895: 32.

${ }^{5}$ Беляшевский 1889: 7.

${ }^{6}$ Петров 1899: 88-108.

7 Де Витте 1900: 86-101.

8 Ляскоронский 1901: 458.

9 Ляскоронський 1927-a: 30.

10 Ляскоронський 1927-b.
} 
Згадані публікації побачили світ саме в той час, коли музейна справа в Україні набула активного розвитку ${ }^{1}$, коли створювалися значні музейні колекції, формувались нумізматичні товариства ${ }^{2}$, здійснювалися перші спроби наукового аналізу накопичених даних. Відродження інтересу дослідників до нумізматики античного часу відбувається лише в повоєнний період. Розглянемо ретельніше найбільш розширені топографічні зведення по знахідках Римських монет на території України, опубліковані в радянську добу.

Так, у викладеному М. Каргером дослідженні давньої історії Києва у 1948 р. згадується також про декілька знахідок римських монет: скарб монет часів Костянтина Великого 3 вул. Глибочицької, а також відомий ще 3 імперського часу Оболонський скарб ${ }^{3}$. Згаданий скарб римських монет, виявлений 1876 р. у садибі Магуріна на Оболоні (сучасний адміністративний район м. Києва, а на період виявлення знахідки - передмістя - Авт.), вартий окремої уваги. У час виявлення комплекс став широко відомим і фігурує у майже всіх топографічних працях. Про нього згадують у своїх працях В. Ляскоронський ${ }^{4}$, В. Антонович ${ }^{5}$, 3-поміж інших знахідок Київщини його називає М. Біляшівський ${ }^{6}$, далі опис скарбу потрапляє до складених М. Брачевським ${ }^{7}$ та В. Кропоткіним ${ }^{8}$ топографій, збережену в архівах інформацію публікує О. Бєлая 9 , також цей скарб не оминають увагою В. Орлик та А. Шостопал ${ }^{10}$.

У 1959 році побачили світ результати розкопок на території Херсонесу, монетні знахідки якого опубліковані А. Гілевичем на базі знахідок сезону 1950 року. В описах фігурує широке різноманіття пізніх монет Римської імперії у поєднанні з одиничними знахідками монет, емітованих від імені широкого кола імператорів на різних монетних дворах ${ }^{11}$.

Комплексним характером та широким охопленням відрізняються топографічні праці, складені М. Брайчевським у 1959 році та В. Кропоткіним у 1961 році. Праця М. Брайчевського «Римська монета на території України» охоплює значний масив даних щодо знахідок римських монет на всій території України. Автор вперше комплексно публікує знахідки, відомі із дорадянського часу, надаючи інформацію про вміст скарбів, короткі свідчення про обставини знахідки. В одну топографію знахідки римських монет з території всього СРСР поєднує В. Кропоткін - «Клады римских монет на территории СССР»,

\footnotetext{
${ }^{1}$ Бойко-Гагарін 2016: 134-145.

2 Зразюк 2017: 132-142.

${ }^{3}$ Каргер 1948: 243-244.

${ }^{4}$ Ляскоронский 1901: 459; Ляскоронский 1927-а: 3.

5 Антонович 1878.

${ }^{6}$ Беляшевский 1889: 26-34.

${ }^{7}$ Брайчевский 1956: 59-64. № 250.

${ }^{8}$ Кропоткин 1961: 59. № 466.

${ }^{9}$ Бєлая 2013: 190-191; Бєлая, Распутіна 2020: 9-10. № 17.

${ }^{10}$ Орлик, Шостопал 2021: 20. № 1.

${ }^{11}$ Гилевич 1959: 191-205.
} 
виділяючи окремою частиною дослідження згадки про монети, виявлені на території УРСР. Основу роботи складають знахідки, опубліковані попередниками $з$ довоєнного періоду, з доповненням їх новими, відомими на той час, даними. Зокрема, автор часто акцентує, що опубліковані ним в топографії знахідки були передані до Краківського археологічного музею. У розширеній топографії В. Кропоткіна згадується про знахідку золотого медальйону Константина I карбування монетного двору Фессалоніки, що була виявлена під час риття окопів у роки Першої Світової війни на Волині; описано монетні знахідки, виявлені під час археологічних пошуків в Тірітаці у 1939 році, нові випадкові знахідки монет Костянтина I та Аркадія в Криму та ін.

Викликають зацікавлення опубліковані обома вченими знахідки пізніх рідкісних римських золотих монет імператора Максиміна I неподалік с. Форнош на Закарпатті; золоті індикації з монет Теодосія 3 Керчі; великий золотий медальйон Константа, проданий на аукціоні після викупу у приватної особи в київському ломбарді у 1898 році; найчастіше зафіксовані мідні монети Костантина I, Констанція I, Констанція II, карбовані в Костантинополі, Нікомедії, Сісції та Антіохії.

У 2000 році була опублікована праця В. Кропоткіна 3 доповненням до попередніх досліджень, виявлених дослідником 3 різних джерел 3 моменту базової публікації 1 , як знахідка 3 Луганщини, опублікована та зафіксована автором для топографії із газети «Луганська правда».

У 1970 - 1980-ті роки фокус уваги дослідників топографії знахідок пізньоримських монет переходить сконцентровано на територію Одеської обл. до наукового обігу вводяться як зафіксовані місцевими дослідниками знахідки, отримані від місцевих мешнкаців, а також передані до музею монет та скарбів. Неопублікованим монетним знахідкам часів Римської імперії на Одещині присвячено працю П. Каришковського ${ }^{2}$.

Важливість уведення до наукового обігу результатів досліджень скарбів важко переоцінити, і тут особливої уваги потребують скарби із колекцій державних музеїв ${ }^{3} .1982$ року під час археологічної експедиції Інституту археології Академії Наук Української РСР під керівництвом А.В. Гудкова було виявлено скарб срібних монет кількістю 93 одиниці, тезаврацію виявив співробітник Фокеєв М. М. У складі монетного депозиту перебувало 93 монети сілікви Констанція II, переважно карбованих на різних офіцинах монетного двору в Константинополі. Комплекс наразі перебуває в колекції Одеського археологічного музею, його вивчено та опубліковано О. Столярик у 1986 році ${ }^{4}$.

\footnotetext{
${ }^{1}$ Кропоткин 2000: 25. № 1760.

${ }^{2}$ Карышковский 1971: 83-84.

${ }^{3}$ Коцур 2017: 15-32.

${ }^{4}$ Столярик 1986: 219-221.
} 
У 1997 році в Сполучених Штатах виходить друком топографічне дослідження О. Столярик ${ }^{1}$. Спираючись на роботи В. Ляскоронського, М. Брайчевського, В. Кропоткіна та П. Каришковського, авторка цитує частину вже опублікованих знахідок, також доповнюючи топографію низкою нових виявлених свідчень про знахідки монет пізнього Риму, здебільшого в Одеській області. Більша частина виявлених О. Столярик пізньоримських монет відноситься до мідного карбування, в окремих районах зафіксовано знахідки також сілікв, в тому числі на особливу увагу заслуговує імітація сілікви 3-під с. Малі Копані Голопристанського району Одеської області².

У 2005 році побачила світ розвідка I. Гавритухіна ${ }^{3}$, присвячена фінальному періодові існування черняхівської культури, в якій автор розглядає монетні знахідки із праць попередників: В. Кропоткіна, О. Столярик, А. Нудельмана. Дослідник відмічає наявність скарбів швидкого накопичення, які вміщують монети періоду Валента (367 - 378 рр.) або Валентиніана I (364 375 pp.).

Знахідки пізньоримських монет на території Криму протягом 2011 2013 рр. вивчає А. Коршенко, особливу увагу приділяючи скарбовим комплексам ${ }^{4}$. Значними за кількістю монет відрізнялись скарби із с. Верхнє Садове, в яких налічувалося 242 монети від випусків Херсонесу до часів імператора Гонорія; скарб з Інкерману з 450 монет, у складі якого були присутні великі мідні фоліси Максиміана (306 - 308 рр.) та Максиміна II (309 - 313 рр.); скарб із с. Червоне Озеро однойменного району в Криму, який налічував 389 монет до часів Гонорія і був виявлений у 2000 році.

Опираючись на архівні джерела, О. Белая публікує окремі згадки про знахідки монет різних історичних періодів на Київщині ${ }^{5}$, а накопичені впродовж професйної діяльності дослідниці дані лягли в основу зведеного каталогу знахідок, який посмертно публікує донька вченої Лідія6 ${ }^{6}$ На особливу увагу заслуговує той факт, що основна частина топографічного зведення дослідниці грунтована головним чином на джерелах із високим ступенем достовірності матеріали архівних справ та періодичної преси, але слід відмітити, що стосовно монет Римської імперії вказані місця знахідок цитовані з уже опублікованих праць В. Ляскоронського, М. Брайчевського, В. Кропоткіна.

Нерідко праці дослідників фокусувались на знахідках з окремих регіонів: знахідки римських монет на Волині ${ }^{7}$ та Харківщині ${ }^{8}$ введені в обіг із аналізом особливостей їхнього розповсюдження та опубліковано К. Мизгіним; монети 3

\footnotetext{
${ }^{1}$ Stoljarik 1997.

${ }^{2}$ Stoljarik 1997: 126, № 163.

${ }^{3}$ Гавритухин 2005: 231-240.

${ }^{4}$ Коршенко 2011: 108-135; Коршенко 2013: 31-32.

${ }^{5}$ Белая 2013: 190-191.

${ }^{6}$ Бєлая, Распутіна 2020.

${ }^{7}$ Мизгін 2019: 34.

${ }^{8}$ Мызгин 2014-2015: 276-287.
} 
Прикарпаття - Л. Вакуленко ${ }^{1}$; знахідки монет на Черкащині, в тому числі античних, згрупував А.Шестопал ${ }^{2}$, розширивши дослідження новими зафіксованими знахідками спільно із В. Орликом ${ }^{3}$. Спираючись на інформацію від місцевих мешканців різних населених пунктів Черкащини, ці дослідники збагатили науку цілим рядом нових монетних знахідок бронзових та срібних монет, надаючи в публікації каталог монет 3 їх детальним описом та визначенням різновидів, що відрізняє це дослідження від багатьох класичних публікацій. Серед монет викликає цікавість солід Феодосія II (408 - 450 рр.), виявлений у 2006 року неподалік с. Хмільна Черкаського району ${ }^{4}$.

Золоті монети. Знахідки золотих римських монет завжди викликають особливу та велику увагу, тому наведемо декілька окремих прикладів подібних знахідок в Україні, опублікованих вченими. Золота монета Феодосія I була виявлена в с. Межигірці Івано-Франківської області; золота монета Юліана II разом із монетами Антонія Пія та Септимія Севера - неподалік селища Чинадійово на Закарпатті, а також золота монета Максиміна I неподалік с. Мисова у Криму5. Про знахідку золотих монет Констанція II, 3 яких було виготовлено підвіски, виявлену у Брестській області, повідомлено В.Сідаровичем 6 . На окрему увагу заслуговують знахідки римських золотих медальйонів, адже кожен із них належить до надзвичайно рідкісних. У складі відомого скарбу монет XVII - XVIII століття із Успенського собору на території Києво-Печерської Лаври виявлено золотий медальйон Констанція II з вушком ${ }^{7}$. Знайдений у 1976 року золотий медальйон Констанція II періоду 337 - 361 років неподалік с. Верхівня Житомирської області та згодом придбаний Музеєм історичних коштовностей України (Інв. № Аu-1345) у громадянина О. Дубини, який стверджував, що знахідку виявлено В.Шевчуком, було опубліковано Б. Гарбузом ${ }^{8}$.

Інформацію щодо окремих нумізматичних знахідок у процесі офіційних археологічних розвідок із наявними монетами Західної Римської імперії було опубліковано археологами А. Гілевич за результатами декількох археологічних сезонів пошуків у Херсонесі ${ }^{9}$, В. Белявцем спільно 3 В. Сідаровичем ${ }^{10}$, В. Кокожару ${ }^{11}$, О. Комаром ${ }^{12}$. Нові знахідки мідних монет Констанція I в

\footnotetext{
${ }^{1}$ Вакуленко 2010: 104.

${ }^{2}$ Шестопал 2007.

${ }^{3}$ Орлик, Шостопал 2021: 17-31.

${ }^{4}$ Ibid: 21 . № 16.

${ }^{5}$ Кропоткин 1961: 76. № 909; 65. № 613.

${ }^{6}$ Сідаровіч 2020: 9.

${ }^{7}$ ЦДІАК. Ф. 128. Оп. 1. Спр. 2990; Петров 1899: 88-108; Кропоткин 1961: 59. № 473; Потин 2000: 30-33; Чернова 2017: 178-182; Орлик, Шостопал 2021: 20. № 4.

${ }^{8}$ Гарбуз 1993-а: 16-17; Гарбуз 1993-b: 71-78.

${ }^{9}$ Гилевич 1959: 191-205.

${ }^{10}$ Белявец, Сідаровіч 2018: 11-12.

${ }^{11}$ Кокожару 1994: 86.

12 Комар 2006: 403-412.
} 
Одеській області протягм 2011 - 2016 років за результатами археологічних досліджень опубліковано I. Бруяко спільно 3 I. Корпусовою, Л. Носовою та Д. Яновим ${ }^{1}$. Про знайдену малу бронзову монету Костантина I під час Комарівської археологічної експедиції Інституту археології НАН України під керівництвом А. Петраускаса опубліковано С. Діденко та К. Мизгіним².

В античну добу поширеним явищем було використання монет як прикрас - надання їм «другого життя». В окресленому хронологічному періоді знахідки монет також відрізнялись значною кількістю срібних та золотих монет iз наявними припаяними вушками, таким чином монети бул перетвореними у підвіски, шийні прикраси. Так, прикраси із 5 сілікв Констанція ІІ було виявлено в районі с. Верхів Рівненської області ${ }^{3}$.

Висновки дослідження. Більша частина знахідок римських монет IV поч. V ст., уведена нумізматами до наукового обігу, відноситься до знайдених у XIX столітті, лише стосовно частини з них збережено відомості про передавання їх до фондів музеїв. У подальшому, практично, одні і ті самі опубліковані знахідки повторно вводились в науковий обіг, переопубліковуючись в різних топографіях знахідок, дещо доповнюючись новими виявленими знахідками монет Західної Римської імперії. Слід відмітити також той факт, що найчастіше в описах до знахідок присутня достатньо скорочена та стисла інформація, відсутні описи монет, вказівка на їх різновиди, здебільшого вказується емітент, номінал, рідше - передається легенда. Прикрим фактом виявилося потрапляння дуже пошкоджених монет, ідентифікація яких можлива лише приблизна, а в опрацьованих авторами топографіях таких повідомлень виявилась досить суттєва кількість.

Найбільш відомими скарбами та знахідками монет, які було опубліковано низкою авторів та згадано в численних публікацях науково-популярного характеру, стали: скарб із села Ласки, сумнівний скарб римських монет 3 історичної Оболоні, знахідки в Успенському та Видубецькому соборах у м. Києві, інформація про які потрапила, практично, в кожне топографічне зведення та до всіх складених нумізматами археологічних карт протягом $\mathrm{XX}$ століття, що зробило їх таким чином класичними скарбами.

Також варто відмітити, що після грунтовних та об’ємних публікацій топографічних зведень по знахідках аничних монет, опублікованих у радянський час, які епізодично доповнювались новими знахідками, в сучасній українській нумізматиці науковцями публікуються знахідки, виявлені як під час офіційних археологічних професійних пошуків, так і несанкціонованих аматорських та випадкових знахідок. На сучасному етапі вивчення цього питання актуальною постає необхідність складання повної топографічної карти знахідок римських

\footnotetext{
${ }^{1}$ Бруяко, Кокоржицкая, Носова, Янов 2017: 51-61. № 10, № 11.

2 Діденко, Мизгін 2012: 367.

${ }^{3}$ Мизгін 2019: 34.
} 
монет IV - поч. V ст. із виконанням їх аналізу для отримання грунтовних висновків щодо поширення та побутування цих монет на території України.

Перспективою подальших досліджень ми бачимо введення у науковий обіг та опрацювання нових знахідок римських монет вказаного періоду на території України 3 метою створення найбільш якісної та наповненої топографічної карти.

\section{References}

Antonovich, V. B. (1878). Opisanie Kievskogo klada, soderzhashchego rimskie monety III $i$ IV stoletiya. [Description of the Kiev hoard containing Roman coins of the 3rd and 4th centuries]. Moskva [in Russian].

Antonovich, V. B. (1895). Arheologicheskaya karta Kievskoj gubernii. [Archaeological map of the Kiev province]. Moskva [in Russian].

Beliavets, V. H. \& Sidarovich, V. M. (2018). Rymskaia manety z selishcha Merchytsy2 Pinskaha rayena. [Roman coin from the village of Merchitsa-2 of Pinsk district]. Abstract of papers: Trэtsiia navukovyia chytanni pamiatsi prafesara Valiantsina Naumavicha Rabtsevicha (1934-2008). [The third scientific readings in the memory of Professor Valentin Naumovich Rabtsevich (19342008).]. Minsk, 16-18 maia 2018 h. Minsk: BDU, 2018. pp. 11-12. [in Belorussian].

Belyashevskij, N. (1889). Monetnye klady Kievskoj gubernii. [Coins of the Kiev province]. Kiev [in Russian].

Bielaia, O. (2013). Arkhivni dzherela pro monetni skarby Kyieva. [Archival sources about the coin treasures of Kyiv]. Pamiatky. Arkheohrafichnyi shchorichnyk. [Monuments. Archaeographic yearbook]. (14). 190-191. [in Ukrainian].

Bielaia, O. M. \& Rasputina, L. A. (2020). Kataloh monetnykh znakhidok Kyivshchyny. [Catalog of coin finds of Kyiv region]. Kyiv: Lohos. [in Ukrainian].

Boiko-Haharin, A. (2016). Dorevoliutsiini hazety yak dzherelo vyvchennia istorii muzeinoi spravy $v$ Ukraini. [Pre-revolutionary newspapers as a source for studying the history of museology in Ukraine]. Kraieznavstvo. [The local lore studies]. № 3/4 (96/97). pp. 134-145. [in Ukrainian].

Bojko-Gagarin, A. \& Myzgin, K. (2014). Koshelek polutornyh groshej Sigizmunda III s denariem Tita iz Zhitomirskoj oblasti. [Sigismund III's wallet of one and a half grosz with a denarius of Titus from the Zhytomyr region]. Visnik Harkivs'kogo nacional'nogo universitetu im. V.N. Karazina. Seriya «Istoriya». [Bulletin of Kharkiv National V.N. Karazin University. History Series]. (48/1117), 240-247. [in Russian].

Bruyako, I. V. \& Kokorzhickaya, T. N. \& Nosova, L. V. \& Yanov, D. M. (2017). Novye monetnye nahodki iz raskopok gorodishcha Kartal / Orlovka 2010$2016 \mathrm{gg}$. [New coin finds from the excavations of the settlement of Kartal / Orlovka during 2010-2016]. Zapiski otdela numizmatiki i torevtiki Odesskogo 
arheologicheskogo muzeya. [Notes of the Department of Numismatics and Toreutics of the Odessa Archaeological Museum]. (3). 51-61. [in Russian].

Chernova, K. (2017). Istoriia skarbu Velykoi tserkvy Kyievo-Pecherskoi lavry XVIIXVIII st. [History of the treasure of the Great Church of the Kiev-Pechersk Lavra of the XVII-XVIII centuries.]. Novi doslidzhennia pamiatok kozatskoi doby $v$ Ukraini. [New studies of memorials of the Cossack era in Ukraine]. (26). 178-182. [in Ukrainian].

Datsiuk, O. \& Boiko-Haharin, A. (2019). Novi nadkhodzhennia do NIAM «Kyivska fortetsia» - monety Olvii, Istrii ta Nikoniiu. [New coin achievements in NIAR «Kiev fortress» - coins of Olvia, Istriya and Nikonii]. Abstract of papers: Problemy i perspektyvy numizmatyky Antychnoi ta Rymskoi doby na terenakh Pivdenno-Skhidnoi Yevropy. [Problems and prospects of numismatics of Ancient and Roman times in South-Eastern Europe]. pp. 20-22. [in Ukrainian].

De Vitte (1900). Arheologicheskaya nahodka v s. Laskove v $1610 \mathrm{~g}$. [Archaeological find in the Laskovo village in 1610]. CHOINL. Chapter. 14. Edition. II. pp. 86101. [in Russian].

Didenko, S. V. \& Myzghin, K. V. (2012). Znakhidky antychnoho importu naposelenni Komariv. [Finds of ancient imports of the Komariv settlement]. Arkheolohichni doslidzhennia v Ukraini. [Archaeological researches in Ukraine]. pp. 367. [in Ukrainian].

Gavrituhin, I. O. (2005). Nekotorye perspektivy izuchenija finala chernjahovskoj kul'tury. [Some perspectives of studying the finale of Chernyakhov culture]. II Gorodcovskie chtenija. Materialy nauchnoj konferencii, posvjashhennoj 100-letiju dejatel'nosti V.A. Gorodcova v GIM. [The Second Gorodtsov readings. Proseedings of the scientific conference dedicated to the 100th anniversary of V.A. Gorodtsov at the State Historical Museum]. pp. 231-240. [in Russian].

Gilevich, A. M. (1959). Monety iz raskopok v Hersonese v 1950 godu. [Coins from excavations in Chersonesos in 1950]. Hersonesskij sbornik. [Chersonesos Digest]. (5). pp. 191-205. [in Russian].

Harbuz, B. B. (1993). Zolotyi rymskyi medalion iz s. Verkhivni. [Golden Roman medallion from Verkhivnia]. Abstract of papers: Мuzeiu istorychnykh koshtovnostei Ukrainy - filialu Natsionalnoho muzeiu istorii Ukrainy. [Museum of Historical Treasures of Ukraine - a branch of the National Museum of History of Ukraine]. Kyiv, 1993. pp. 16-17. [in Ukrainian].

Harbuz, B. B. (1993). Zolotyi rymskyi medalion z s. Verkhivni. [Golden Roman medallion from Verkhivnia]. Arkheolohiia. [The archeology]. (1). 71-78. [in Ukrainian].

Kalakura, Ya. S. \& Voitsekhivska, I. N. (2002) Istorychne dzhereloznavstvo. Pidruchnyk dlia studentiv istorychnykh spetsialnostei vyshchykh navchalnykh 
zakladiv. [Historical source studies. Textbook for students of historical specialties of higher educational institutions]. Kyiv: Lybid. [in Ukrainian].

Karger, M. (1948). K voprosu o drevnejshej istorii Kieva. [On the question of the ancient history of Kiev]. Moskva [in Russian].

Karyshkovskij, P. O. (1971). Nahodki pozdnerimskih $i$ vizantijskih monet $v$ Odesskoj oblasti. [Finds of late Roman and Byzantine coins in the Odessa region]. Materialy po arheologii Severnogo Prichernomor'ya. [Materials on the archeology of the Northern Black Sea region]. (7). 83-84. [in Russian].

Kokozharu, V. M. (1994). Novye monetnye nahodki rimskogo vremeni v okrestnostyah goroda Reni na Dunae. [New coin finds from Roman times in the vicinity of Reni on the Danube]. Abstract of papers: Problemy skifo-sarmatskoj arheologii Severnogo Prichernomor'ya. [Problems of the Scythian-Sarmatian archeology of the Northern Black Sea region]. Tom II. Zaporozh'e. pp. 86. [in Russian].

Kolybenko, O., \& Kolybenko, O. (2016) Znakhidky olviiskykh monet na Pereiaslavshchyni. Abstract of papers: «Aktualni problemy numizmatyky $v$ systemi dopomizhnykh istorychnykh dystsyplin». 22-23 chervnia 2016 r. Kirovohrad-Kyiv-Pereiaslav-Khmelnytskyi, 2016. pp. 18-21. [in Ukrainian].

Komar, A. V. (2006). Pogrebenie kochevnika nach. VIII v. u sela Zhuravliha v Srednem Podneprov'e. [Burial of a nomad at the beginning of the 8th century near the village of Zhuravlikha in the Middle Dnieper]. Stepi Evrazii v epohu srednevekov'ya. [The steppes of Eurasia in the Middle Ages]. (5). 403-412. [in Russian].

Korshenko, A. N. (2011). Krymskie klady pozdnerimskih monet. [Crimean hoards of late Roman coins]. Numizmatika i epigrafika. [Numismatics and epigraphy]. (18). 108-135. [in Russian].

Korshenko, A. N. (2013). Novyj klad pozdnerimskih monet iz Yugo-Zapadnogo Kryma. [New hoard of late Roman coins from Southwestern Crimea]. Abstract

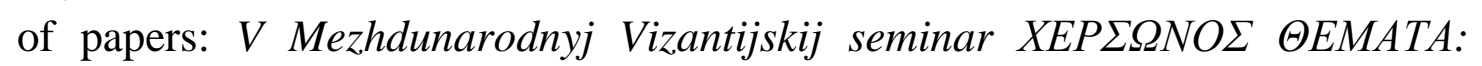
«imperiya» $i$ «polis». [International Byzantine Seminar XEP $\Omega$ NO $\Sigma$ @EMATA: «empire» and «polis»]. Sevastopol. pp. 31-32. [in Russian].

Kotsur, V. (2017). Istoriohrafiia ukrainskoho skarboznavstva. [Historiography of Ukrainian treasury]. Ukrainskyi numizmatychnyi orichnyk. [The Ukrainian numismatic annual]. (1). 15-32. DOI https://doi.org/10.31470/2616-6275-20171-15-32. [in Ukrainian].

Kotsur, V. (2020). Numizmatychne zibrannia Natsionalnoho istoryko-etnohrafichnoho zapovidnyka "Pereiaslav». [Numismatic collection of the National Historical and Ethnographic Reserve «Pereyaslav»]. Ukrainskyi numizmatychnyi shchorichnyk. [The Ukrainian Numismatic Annual]. (4), 144-164. https://doi.org/10.31470/2616-6275-2020-4-144-164 [in Ukrainian].

Kotsur, V. P. (2013). Aktualni napriamy ta orhanizatsiini zasady suchasnykh doslidzhen serednovichnoi numizmatyky $v$ Ukraini. [Current trends and 
organizational principles of modern studies of medieval numismatics in Ukraine]. Naukovi zapysky z ukrainskoi istorii [The scientifical notes of the Ukrainian history]. (33), 3-8. [in Ukrainian].

Kotsur,V. (2016). Methodological issues of modern numismatic research: materials of black archeology and scientific research. Abstract of papers: Studia I Materialy Forum Numizmatyczne, Pieniadz I Mennice, (1), (pp. 5-9). [in English].

Liaskoronskyi, V. H. (1927). Rymski monet; yaki znaideno na terytorii m. Kyieva. [Roman coins founded in Kyiv]. Kyiv. pp. 3. [in Ukrainian].

Lyaskoronskij, V. G. (1899). Nahodki rimskih monet $v$ oblasti srednyago Podneprov'ya. [Finds of Roman coins in the middle Dnieper region]. Trudy odinnadcatogo arheologicheskogo s'ezda v Kieve. [Proceedings of the Eleventh Archaeological Congress in Kiev]. Tom I. Moskva. [in Russian].

Lyaskoronskij, V. G. (1927). Rimskaya moneta v predelah Yuzhnoj Rusi $i$ v sosednih s neyu zemlyah. [Roman coin within Southern Rus' and neighboring lands]. The maniscript. Kiev. Library named after Maksimovich. Inv. № 182989. [in Russian].

Mielczarek, M., \& Orlyk, V. (2019). New find of Olbian coins. Tarashcha district, Kyiv region, Ukraine. Skhidnoievropeiskyi Istorychnyi Visnyk [East European Historical Bulletin], 13, 33-39. doi: 10.24919/2519-058x.13.190763

Myzghin, K. V. (2019). Znakhidky rymskykh monet na Volyni: osnovni katehorii ta osoblyvosti rozpovsiudzhennia (do problemy rehionalnoho vyvchennia). [The Roman coin finds in Volhynia: main categories and features of distribution (to the problem of regional study)]. Arkheolohiia $i$ davnia istoriia Ukrainy. [Archeology and ancient history of Ukraine]. (1(30)). 34. [in Ukrainian].

Myzgin, K. V. (2014-2015). K karte nahodok antichnyh monet na Har'kovshchine (iz nauchnogo arhiva B. P. Zajceva). [To the map of finds of antique coins in the Kharkiv region (from the scientific archive of B.P. Zaitsev)]. Drevnosti. [The Antiquities]. pp. 276-287. [in Russian].

Orlyk, V. \& Orlyk, S. \& Luzanova, A. (2020). Informatsiinyi potentsial ofitsiinykh saitiv muzeiv u numizmatychnykh doslidzhennia ta populiaryzatsii diialnosti muzeinykh ustanov. [Information potential of the official museum WEB-sites in the numismatic researches and promotion of museum institutions]. Sotsium. Dokument. Komunikatsiia. [Society. Document. Communication]. (10). 392422. DOI: 10.31470/2518-7600-2020-10-392-422. [in Ukrainian].

Orlyk, V. \& Shostopal, A. (2021). Numizmatychni svidchennia zviazkiv naselennia dniprovskoho pravoberezhnoho lisostepu $z$ Rymskoiu ta Vizantiiskoiu isperiiamy $u I V$-VIII. [Numismatic evidences of the connections of the population of the Dnieper right-bank forest-steppe with the Roman and Byzantine empires in IV-VIII cent.]. Forum Numizmatyczne. Studia i materiaty. (5). 17-31. [in Ukrainian]. 
Orlyk, V. (2018). Skarb ol'viys'kykh «borysfeniv» iz s. Yaselka Ochakivs'koho rayonu Mykolayivs'koyi oblasti. Aktual'ni problemy numizmatyky u systemi spetsial'nykh haluzey istorychnoyi nauky: tezy dopovidey V-yi mizhnarodnoyi naukovo-praktychnoyi konferentsiyi, 21-22 chervnya 2018 r. Medzhybizh Pereyaslav-Khmel'nyts'kyy - Kropyvnyts'kyy - Kyiv, S.13-14. [in Ukrainian].

Orlyk, V. (2020). Znakhidka kyzikiny-hekty v seredyni 90-kh rokiv XX st. poblyzu s. Parutyne. [The discovery of kizikin gekta in the mid-90s of XX century. near the village Parutine]. Abstract of papers: Studia I Materialy «Forum Numizmatyczne». (4). 5-15. [in Ukrainian].

Orlyk, V. (2020). Znakhidky monet Pontiiskoi derzhavy Mitridata Yevpatora na terytorii Dniprovskoho Pravoberezhnoho Lisostepu. [Coin finds of the Pontic state of Mithridates of Evpator on the territory of the Dnieper Right-Bank Forest-Steppe]. Ukrainskyi istorychnyi zhurnal. [The Ukrainian Historical Journal]. (6). 93. [in Ukrainian].

Orlyk, V. (2020). Znakhidky v baseini r. Tiasmynu midnykh monet Olvii z Demetroiu ta «istriiskym» variantom miskoi emblemy. [Finds in the basin of the Tyasmin River of copper coins of Olbia with Demetra and the «Istrian» version of the city emblem]. Ukrainskyi numizmatychnyi shchorichnyk. [The Ukrainian numismatic annual]. (4). 5-42. DOI: 10.31470/2616-6275-2020-4-5-13. [in Ukrainian].

Orlyk, V. M. (2013). Informatsiinyi potentsial WEB-resursiv u numizmatychnykh doslidzhenniakh (na prykladi monet derzhav Khrestonostsiv) [The informational potential of the WEB-resources (on example of coins of the Crusader States)]. Arkhivoznavchi ta dzhereloznavchi haluzi znan: problemy vzaiemodii na suchasnomu etapi [Archival and source knowledge sciences: problems of interaction at the present stage], pp. 129-133. [in Ukrainian].

Orlyk, V. M. (2020). Do pytannia isnuvannia hroshovoho obihu na terytorii Dniprovskoho pravoberezhnoho lisostepu (V-I st. do n.e.). [On the question of the existence of money circulation on the territory of the Dnieper right-bank forest-steppe (V-I centuries BC).]. Abstract of papers: Istoriia, arkheolohiia, informatsiina, bibliotechna ta arkhivna sprava: aktualni problemy nauky ta osvity. [History, archeology, information, library and archival affairs: current problems of science and education]. pp. 9-13. [in Ukrainian].

Orlyk, V., Kotsur, V. \& Tsyganenko, L. (2019). Klad ol'viyskikh monet «borisfenov», naydennyy $v$ Gorodishchenskom rayone Cherkasskoy oblasti vesnoy 2018 goda. Acta Archaeologica Lodziensia, 65, 37-48. [in Russian].

Petrov, N. (1899). Arheologicheskaya nahodka na horah velikoj cerkvi Kievopecherskoj lavry. [Archaeological find in the choirs of the great church of the Kiev Pechersk Lavra]. Chteniya $v$ Cerkovno-Arheologicheskom obshchestve. [Readings in the Church-Archaeological Society]. (2). 88-108. [in Russian]. 
Potin, V. M. (2000). Sokrovishcha monastyrskoj kazny (Kievo-Pecherskij klad $1898 \mathrm{~g}$.). [Treasures of the monastery treasury (Kiev-Pechersky treasure 1898)]. Numizmatika $i$ faleristika. [Numismatics and faleristics]. (4). 30-33. [in Russian].

Priadko, O. \& Yurchenko, O. (2017) Novi znakhidky rymskykh monet na Pereiaslavshchyni. [New finds of Roman coins in Pereyaslav Region]. Nizhynska Starovyna. Seriia Pamiatkoznavstvo Pivnichno-Skhidnoho rehionu Ukrainy. 9.24 (27). 84-91. [in Ukrainian].

Shestopal, A.V. (2007). Skarby Cherkashchyny [The treasures of Cherkasy]. Cherkasy: Vyd. Androshchuk P.S. [in Ukrainian].

Sidarovich, V. M. (2020). Rymskiia manety - pershyia hroshy na Belarusi. [Roman coins as the first money in Belarus]. Bankauski vesnik. [Banking Herald]. P. 9. [in Belorussian].

Stoljarik, E. S. (1997) Essays on Monetary Circulation in the North-Western Black Sea Region. Univ Museum Pubns (1 Oct. 1997). [in English].

Stolyarik, E. S. (1986). Klad rimskih serebryanyh monet IV v. iz s. Holmskoe Odesskoj oblasti. [Hoard of Roman silver coins of the 4th century from Kholmskoe, Odessa region.]. Vizantijskij vremennik. [Byzantine timeline]. (47 (92)). 219221. [in Russian].

Vakulenko, L. V. (2010). Znakhidky rymskykh monet u Prykarpatti ta pytannia hroshovoho obihu. [Finds of Roman coins in the Carpathians and the question of money circulation]. Arkheolohiia i davnia istoriia Ukrainy. [Archeology and ancient history of Ukraine]. (4). 104. [in Ukrainian].

Zraziuk, Z. O. (2017). Z istorii numizmatychnoi kolektsii Tserkovno-Arkheolohichnoho muzeiu pry Kyivskyi dukhovnii akademii. [From the history of the numismatic collection of the Church-Archaeological Museum at the Kyiv Theological Academy]. Ukrainskyi numizmatychnyi shchorichnyk. [The Ukrainian numismatic annual]. (1). 132-142. DOI: 10.31470/2616-6275-2017-1-132-142. [in Ukrainian]. 